\title{
Erosion of Ethics in Credit Derivative: A Case Study
}

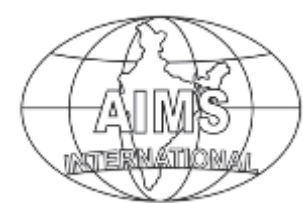

ISBN: 978-1-943295-16-6

\author{
Sumit Kumar \\ Pankaj Kumar Baag \\ Indian Institute of Management \\ (sumit01phdpt@iimk.ac.in) \\ (baagpankaj@iimk.ac.in)
}

\begin{abstract}
This paper studies the erosion of ethics in credit derivative leading to devastating losses to a financial intermediary, JP Morgan, in a scandal that had one of its protagonists earning the moniker the "London Whale." In the process, the paper suggests that the higher management will have to foresee how the limitations are imposed on the market values of the synthetic credit portfolio to avoid further breaches to be caused in other bank metrics. The accounting sectors will have to consider sub-methods like an integrated financial information system for purposes of accuracy to prevent the London whale from economic depressions.
\end{abstract}

Keywords: Credit Derivative, Ethics, Hedging, London Whale, JP Morgan

\subsection{Understanding Ethics in the context of a financial system}

\section{Introduction}

Ethics can mean different things to different people. However, the general agreement is the right ethics in finance revolves around being faithful in all engagements and under all circumstances to be open and promote all parties' interests in a transaction. As Iqbal and Mirakhor (2017) posit, the rapid technological changes of the past several decades continue to cause challenges that border on moral decadence and ethical malpractices occasioned by vastly evolving cultural changes. The need for ethics in the capital markets is meant to achieve a balance for fairness and efficiency (Conrad, 2018). Thus, ethical considerations help prevent 'moral hazards', a term Conrad (2018) associates with the management's pursuit of corporate wealth to the detriment of everyone else. Fairness is achieved when there is a level playing ground for everyone, ensuring full disclosure of all material information and easy access to it.

While news of investors losing hard cash in the financial markets has frequently been met with public dismay and fury over the fraudulent acts, the incidences continue nonetheless. These incidences have sometimes resulted from individuals in the financial market seeking personal gain by taking advantage of loopholes within the financial system. But, at other times one could argue that there exists negligence on the part of financial regulators (Jagoand Pfeffer, 2019; Toms, 2019).

More alarming, however, is the case of corporate executives resorting to practices that border on ethical malpractices in pursuit of more profits and illusions of exemplary financial performance, be it though on paper only. While the first case could result in potential criminal proceedings, often, the second case is hard to pin down on individual culpability and mostly arise due to poor corporate culture (Smimou, 2020; Hassan et. al., 2017). These cases of accounting fraud and manipulations seriously erode public confidence in the capital markets.

\subsection{Understanding Ethics in the Context of a Credit Derivative Business}

Whilst governments and regulators continue to put up a fight against financial misconduct among the financial market players, their efforts seem meek and coming too late in the day. Through formulations of regulatory frameworks to address emerging ethical problems, the government and regulatory bodies seem to only put out old fires, with new ethical problems springing up immediately thereafter.

Even then, Vujnovic-Gligoric et. al., (2018), writes that compliance with regulation alone is not sufficient to eradicate such ethical behaviour. They argue that the prevailing regulatory framework and instruments of investor protection have, thus far, proved inadequate for control purposes. Hence, there is an urgent need to create a robust set of operating ethical principles to address emerging ethical issues (Vujnovic-Gligoric et. al., 2018). What is not in doubt, however, is the fact that the decline in ethical values always seems to stem from not only ignorance and misconceptions, but also from the criminalization of market act behaviour and wrongful evaluation of money as observed by Greenwood and Freeman (2018).

How then should we determine what constitutes ethics and how companies and individuals should discern and be able to make ethical decisions? Recent research points to guiding principles that can help us to test for ethical behaviour through a three-way test (Chuang and Chiu, 2018; Afsar and Shahjehan, 2018). These are as follows:

- The first test involves legal respect, whereby decision taken must be in line with prevailing laws to be regarded as ethical.

- The second test is through fairness, which means providing equal advantages and disadvantages to all concerned parties.

- The third test is of moral judgment, determined by figuring out if the decision taken is made public it will bring shame (Hoekstra and Kaptein, 2020).

Scholars argue that the derivatives market offers a platform that is most conducive for players keen to make a profit from their hedging, the perfect platform to bend some ethical practices and norms in pursuit of profits (Garicanoand Rayo, 2016; Huanand Parbonetti, 2019). In a sense, derivatives represent financial instruments that derive value from other products, which may be physical or financial such as bonds, currency, commodity, or stock. These other products are commonly 
referred to as the underlying instrument. The primary forms of derivatives exist as futures, forwards, options, and credit derivatives swaps.

Going back, financial derivatives gained popularity from the 1970s, starting out in Chicago (Leins, 2018, Grimaand Thalassinos, 2020). They have now expanded to be a feature in the global markets and equally spread in the form with new contracts being invented. Derivative's invention provided financial market participants with a way to manage risks like change in prices, exchange rates, interest rates, or market liquidity. The amount traded through derivatives has risen over the years, hitting astronomical figures in some instances.

According to Lartey (2020), financial derivatives by virtue of being contractual in nature, must incorporate strong ethical practices, with ethics playing a significant role as with all contracts. To avoid differing interpretations whereby contracts are breached with impunity, there is a need to uphold the right ethics. They are equally relevant in maintaining relations of corporations with employees, customers, suppliers, and other stakeholders. Imperfect contracts are due to limitations in cognitive ability, incomplete knowledge, bounded rationally, and future contingencies (Schoen, 2017). Breach of agreements results in disagreements and legal repercussions when they are vague and contain ambiguity or incompleteness, which is an ethical problem.

What does then unite all the different financial derivatives is the need to manage risk. Businesses assess risks and decide which ones they are comfortable handling and what they can lay off. Also, derivatives are a means of creating revenue as they provide an alternative means of investing. Their significance lies in the lower transaction costs and the possibility of price arbitrage. Price arbitrage is the gain received from trading on differences from prices of the derivative and the underlying asset or differences in prices of differing markets. However, even though derivatives are a means to manage risks, there is a major concern particularly with regards to the risks and uncertainties they portend (Cavusgil et. al., 2020). Therefore, derivatives seem to be insufficient as the questionable issue is whether this approach and such trades are beneficial to society as a whole or beneficial to parties that only hold an interest.

As with all other derivatives, credit derivatives are a financial contract between two parties: banks, natural hedge funds, or insurance companies, for the exchange of money or financial instruments under credit circumstances. This involves a scenario where one party seeks to mitigate the risk that one or more credit instruments in its portfolio will default. The other party then receives insurance premiums by offering to ensure the buyer and protecting against loss. Credit derivatives have elicited the most criticism as a financial derivative, even receiving strong condemnation from The Pope. In a Vatican statement, the Pope castigated the derivatives as unethically unacceptable, comparing them to a ticking time-bomb and lamenting that they are designed to marvel in others' ruin, which is very unfortunate (Natarajan, 2018). Writing for Berkshire Hathaway's 2002 annual letter, none than the world-renowned Warren Buffet, offered this scathing warning about financial derivatives, laments that derivatives would soon turn to be 'financial weapons of mass destruction,' though he would, predictably, proceed to use them to mint millions from it later on (Lewitinn, 2016)

CDS, as with all derivatives, was initially designed as a means to help financial institutions hedge against default risks. However, in the build-up to the financial crisis of 2007, companies began to use them to amplify their bets on the performance of a company as they are useful instruments of speculating on a company's creditworthiness. Here then, CDS seems to have crossed the line as a hedging tool, evolving overnight as a tool of speculation offering unmatched profitability, but with the possibility of massive losses, more or less, just how but a gamble. And this is exactly what happened to JP Morgan with Ikshil, their senior trader, coming up with a risky speculative hedging plan that backfired spectacularly.

While it is true that every business venture involves a certain degree of risk, some risks, while promising massive returns, could prove too expensive and too reckless to undertake. Scholars agree that risk in business could portend new potential for new opportunities, which plays a contributory role in creating a functional and productive economy (Trang and Tho, 2017; Neuhann and Sockin, 2020; Abdelaziz, and Abed, 2018). The determinant factor in risk is the impact that a specified transaction has on the aggregate level of risk that the society has to bear. Through the transformation and transferring of risk, the individual trader is shielded from risk by reducing the risk or maintaining it at the same level. However, derivative transactions can result in the rise of the aggregate level of risk, which hurts the economy, more so on the general population who are not involved in the transaction. This then raises ethical concern as the burden is borne by groups who have not created the risk. Thus, derivatives have social externalities. Furthermore, those affected receive no compensation for the infringement of their rights, including loss of welfare.

\section{The London Whale Case Study}

\subsection{Introduction}

The London Whale did cost JP Morgan Chase a whopping \$6.2 billion loss in 2012 from trading in the synthetic credit portfolio. The case study raised important questions on the banks' addiction to risk and greed. In a way, what Chief Investment Officer (CIO) at JP Morgan did was the same old narrative. They doubled down after a loss from trade with even bigger gambles hoping that their big gambles would lead to a huge payday. Below is the timeline given in Table 1 culminating to the discovery of a financial scandal which the media christened the 'London Whale'

However, plenty more was wrong. The CIO's job at the bank, it would appear, was to hold down the bank's level of credit risk. However, the CIO office used hundreds of billions of dollars at its disposal to speculate, as opposed to hedging, (a greater proportion emerged from deposits, which the company realized was always greater than the loans they issued) and to emerge as a money-maker. The CIO office was engaged in a web of complex derivative trading and little to do with hedging. 
For example, a single trade by the CIO could at times net as much as $\$ 400$ million. The trouble reared its head in early 2012 when JP Morgan began to pursue a policy aimed at reducing its Risk-weighted Assets in line with the imminent changes in bank capital regulations otherwise referred to as Basel III. The risk was then reduced by engaging in more offsetting gambles. Above all, the London Whale case study raises a number of ethical questions related to the greed and appetite for greater risk and cover-ups when the risks begin to be overbearing.

Table 1 Timeline of discovery of London Whale

\begin{tabular}{|c|c|c|c|c|}
\hline $\begin{array}{c}\text { Dec-2011 } \\
\text { Net and credit index } \\
\text { of } \$ 51 \text { billion }\end{array}$ & $\begin{array}{c}\text { Jan-2012 } \\
\text { Mark to market losses of about \$ } \\
100 \text { million Leading to the creation } \\
\text { of a new VaR model }\end{array}$ & $\begin{array}{c}\text { Feb-2012 } \\
\text { Incurred } \$ 169 \text { mark to } \\
\text { market losses }\end{array}$ & $\begin{array}{c}29^{\text {th }}-\text { mar-2012 } \\
\text { Loss of about } \$ 400 \\
\text { million was recorded } \\
\text { (mark to market) }\end{array}$ & $\begin{array}{c}30^{\text {th }} \text {-mar-2012 } \\
\text { The bank lost } \$ \\
\text { about138 } \\
\text { million }\end{array}$ \\
\hline $\begin{array}{l}\text { 5-Apr-12 } \\
\text { The sending of the } \\
\text { email by the } \\
\text { JPMorgan CFO }\end{array}$ & $\begin{array}{l}\text { 6-Apr12 } \\
\text { The presentation of the London } \\
\text { whale article }\end{array}$ & $\begin{array}{c}\text { 6-Apr-12 } \\
\text { Recurrent losses forcing Grout } \\
\text { to cross-examine the initially } \\
\text { made analysis }\end{array}$ & $\begin{array}{l}\text { 13- Ar-12 } \\
\text { The earnings call to the } \\
\text { public and investors }\end{array}$ & $\begin{array}{l}\text { 26- Apr-12 } \\
\text { Exposure of the } \\
\text { entire firm risk }\end{array}$ \\
\hline $\begin{array}{l}\text { 10- May -12 } \\
\text { Disclosed almost } \\
\text { \$2 bilion losses }\end{array}$ & $\begin{array}{l}13 \mathrm{Jul}-12 \\
\text { \$5.8 million loss in mark to market }\end{array}$ & $\begin{array}{l}\text { 16-Jan- } 13 \\
\text { The presentation of the } \\
\text { JPMorgan Chase report }\end{array}$ & $\begin{array}{l}\text { Sept-13 Fined } \\
\$ 920 \text { million }\end{array}$ & $\begin{array}{l}16 \text {-oct-13 } \\
\text { Fined } \$ 100 \\
\text { million }\end{array}$ \\
\hline
\end{tabular}

Source: Authors Own Source

\subsection{Synthesis of the Event "London Whale"}

In the recent past, banks have gained greater access to credit derivatives, which is relatively a rich class of securities, and which are in fact, actively trade. The extent of the transfer of risks within the banking industry has, as a consequence, increased tenfold. Banks are not just interested in making loans and then holding them either till they mature or charge off. Rather banks have a greater appetite to consider transacting excess deposits an engage in counter-party deals where the creditrisk exposure shifts with the decrease in the overall risk given to the original lender. Hence, it might be easy positing, therefore, that the supply of derivatives hedges off on the credit risk. Perhaps, it is this divergent position that informs MacIntyre's (2016) argument that people may measure themselves and their activities either by the standards of virtue or by the standards of money, but not both. People must always choose one. The argument could mean the whole saga of the 'London Whale' was a choice that Mr Iksil and his colleagues had already made to measure their activities by the standards of money and not those of virtue.

Unlike the position held by MacIntyre (2016), Rochiand Thunder (2019) argument rests on the premise that the financial sector can respond positively to reforms, and that there are conditions under which traders can both be good at their job (effective at trading) and concurrently live a worthy human life (life of virtue). Generally, ethics involves ways of answering questions anchored on issues/events that are either illicit or licit or those that are considered to be morally permissible. Business ethics often require complete compliance with moral and legal norm. Hence, the 'London Whale' case study provides a good valid reason to reflect on Maclntyre's argument that under certain conditions, security traders face ruthless and possibly even alluring urge to opt for unethical forms of conduct.

Bruno Iksil, who was a JP Morgan chase trader, when the company's chief executive officer was released in a press conference that the bank had lost billions of dollars in the Q2 of 2012 arising out of certain unsuccessful aggressive trading tactics. At the press conference, the head of the company admitted to an error in judgment by the top management as the contributors to the huge losses (Sale, 2013).

Mr. Iksil, though just a subordinate of the CIO was a senior trader of no mean feat dealing in credit default swaps. In mid2012, the bank realized that the positions open by the trader were huge and that there were massive losses. For banks, money is vital, obviously, however, in this specific case, the bank's problems were linked to the image and the trusts that investors have on them rather than merely profits. For large investment banks in the mould of JP Morgan Chase, the loss of about \$2 billion is recoupable in a few quarters; however, when the company's image is soiled, then it can take quite a lot to recover.

For the sake of this analysis, the most fascinating aspect of the case is that the chief architect of the whole thing, Mr- Iksil, also nicknamed, the 'London Whale', suffered retribution, as a trader for the events that happened from his direct boss, who authorized the transaction, and it is believed that he acted within the relevant legal requirement. What he did was part of what was required of him. During the hearings and investigations after the debacle, He was adjudged innocent.

\subsection{Issue of Ethics}

While the general policy of selfishness is all about doing whatever one desires or whatever provides the greatest pleasure, ethical egoism does not. Ethical egoists would by nature concerned with how their actions and interactions affect other people. On most occasions, ethical egoists are perhaps better off working with other people and avoiding actions that may rile other people. Often, ethical egoism is associated with a general policy of selfishness, which refers to the disregard of the interest of other people in favour of one's interests.

As is so often observed, selfishness translates into survival value, at least from a biological perspective (Bonin, et al., 2020). For example, a woman who runs away from a burning building, when there is a chance to save someone else's infant, 
is essentially selfish. For an ethical egoist, only a move that will serve self-interest will be considered in such a scenario. At the same time, for an opportunity to be seen as a hero, that woman might rush into the building to save the child, given that there is some chance for the baby to be saved.

Psychological egoism is a belief that others always act to suit self-interest even when the act seems to be unselfish. It backs the belief that others can willingly assist anybody with the anticipation of eventually receiving some benefit from the act, directly or indirectly. Ethical egoism is a philosophical paradigm that states that any consequence that results in actions that benefit the doer of the action is ethical. Hence the difference between these two terms is that psychological egoism posits that people perform behaviours that meet their self-interest. It means that it is a descriptive perspective of what pushes individuals to act.

Conversely, ethical egoism is more of a philosophical construct that says any consequence of an act that benefits the doer is morally appropriate. See, psychological egoism is a descriptive concept based on actual observation, and it does not provide suggestions and neither does it provide judgments that can be considered immoral or moral. On the other ethical egoism assumes a normative tone, and states what is moral within the divide between wrong and right. In this case, Kantian ethics demand for universality in the application makes little sense, practically, though one can grant there is value in having a pure ideal. Those that draw their ethics significantly from Kant take a large leap of faith, both to believe as well as in their philosophies. On the other hand, virtue ethics drives many people, but there is a self-reflection problem: if one acts "morally", according to their virtues, what if what they perceive as virtue is not? As much as one can let consequentialism shape his dayto-day actions more than other paradigms, this leads to interesting effects, such as doing something ethical, with respect to the broader consequences, but may not be reflective of what would be "moral" if one follows a more virtue ethics stance.

\subsection{The case Development and Comparative Analysis}

The London Whale in the case study had gone long and in a big way on credit default swaps, and this means that he sold vast amounts of protection against the credits making up the index. When a conference call with market analysts, Braunstein, who was the bank's CFO admitted that the positions meant to hedge investments the banks make in extremely top-grade assets with excess deposits. He also admitted that the chief investment position was made consistent with JP Morgan Chase's overall risk strategy. The dynamic hedging had assumed that the markets would remain efficient. This did not work out as thought. The huge trade had ended up distorting the index itself, i.e. the index became cheaper than the constituents. Hedge funds were aware of this big position and then used skew trades to "express" this view

Hedge funds saw this difference and started arbitrage. They waited for the divergence to die down. But the market did not correct. The London Whale was actually selling vast amounts or protections and then sitting on them to an extent that the market could not autocorrect. The trade unwinds factor. In the meantime, the person engaged in selling possibly developed some cold feet. As has been stated, the person possibly stopped re-balancing the hedged, and this possibly led to an increase in the risk as well as the losses. From the bank's 10-Q form, since March 2012, the chief investment office incurred substantially mark to market losses in its SCP and which has proven to be greatly risky, and even more volatile as well as not effective as a financial hedge that the firm had believed previously. In short, JP Morgan's trade ended up distorting the market but eventually led to a massive loss due to a large unhedged exposure. The loss only goes to show how weak the legal regulatory system in place. The CEO of JP Morgan Chase was adamant and possibly right, in admitting that Mr. Iksil's gamble was legally complaint, despite the fact that they obviously violated the spirit of the Volcker Rule, and possibly, the market regulators will listen more to the Occupier's letter because the bank has now possibly fashioned risk management.

If JP Morgan Chase cannot do it, then there is no bank that can do it. He was hedging JP Morgan's credit risk, which is not marked to market. If corporate credit improved, you would expect that hedge to lose money, although JP Morgan as a firm would net profit, because the value of its loans to corporations and other businesses would go up. However, that's not why the whale lost money. The whale made complex bets. The bets were large enough to move the markets in their direction, which led to high paper profits and low reported risk. It's like if you buy a stock and keep buying, the price goes up and you look as if you're making money. Hedge funds noticed the prices going up, and took the other side, pushing prices back down and creating losses. These losses required JP Morgan to post cash collateral. Also, the losses made the positions look much riskier to the bank's risk models. Senior management decided to back away from the strategy, which locked in the losses but prevented further losses. No one knows whether that was wise or foolish, but it was foolish to go into the strategy without clear support from the top. If you're going to allow a trader to bet the bank, make sure everyone knows it, so you won't call off the game in the middle. First of all, the goal of risk management is not to prevent disaster. Attempting that just chokes off innovation and blocks the profits you need to cushion the inevitable bad surprises. Instead, the goal is to come up with a coherent view of risk and ensure all stakeholders know it (they don't have to agree with it) and accept a negotiated strategy for managing it. This clearly did not happen at JP Morgan.

The basic story is a common one. The bank had more risk exposure than it wanted, in this case to European corporate credit risk. This is inherent to a bank's business; part of its job is to understand credit risk and make bets on it. But it also looks for cost-effective ways to lay off some of that risk, just like an insurance company might buy reinsurance against an unexpectedly large amount and size of claims. JP Morgan appointed a trader to lay off European credit risk in an opportunistic manner. That is, they didn't want him just to buy general protection at the going rate, but to pick and choose, buying protection when and where it was cheap, and retaining credit risk when and where protection was overpriced. The trader went further and actually sold protection when and where it was overpriced. His net exposure was still long protection; that is his positions made money in a general credit decline. And their net size was what the bank wanted. But their gross size 
was much larger, meaning he made large profits when credit didn't move if he guessed right about where things were overpriced and under-priced. Of course, that opens up the possibility of large losses if he's wrong.

This happens all the time on Wall Street. Outsiders hate it. They see a guy hired to buy insurance who instead runs off to Las Vegas to make wild bets. They are appalled at the excessive gross leverage caused by long and short partially offsetting positions. But it's accepted practice on Wall Street. You could hire a clerk cheaply to buy insurance in a systematic way, kind of like running an index fund. But leading financial institutions make their money by hiring top people and giving them the chance to make extraordinary profits for themselves and the bank; at the risk of costing extraordinary losses for the bank and losing their jobs. You can't get top people to do rote insurance buying, and sending less than top people to financial markets with deep pockets is an invitation to get taken.

One strategy used by the London Whale, in simplified form, was to buy under-priced credit protection on an index, then sell overpriced credit protection on some of the individual names that JP Morgan did not have exposure to. Another was to double the amount of protection he needed in 5-year swaps and sell at once the amount he needed in a 10-year swap. If credit spreads went up or down the position approximately broke even, because the ten-year value moved twice as much as the five years. But in an actual default within five years, he collected twice and paid once, so he was insured. This captured the protection against actual default that JP Morgan needed, while not paying for-actually profiting from-ups and downs of market estimates of future default probability. This is what creates the need for sophisticated risk management. With individuals making large complex bets, it is imperative that everyone understand the risks.

There are three main risk management tools for this: value at risk, stress tests, and scenario analyses. The London Whale always did fine on stress tests, and no one has questioned their accuracy. In any plausible combination of actual default events, even extreme ones, the positions made money in line with JP Morgan's overall net exposure goals. A stress test is an instantaneous shock to market prices. Scenario analyses are stories of events in sequence; A happens, we trade B, C happens, we trade D, and so on. These were more controversial. They did show some scenarios in which the portfolio had a large mark to market losses, but not as large as occurred. This does not contradict the stress tests. You can have a position that makes money if a company defaults and if it doesn't default. So your stress tests are fine. But there might be intermediate times when the default is uncertain where your position has a large mark to market losses, for which you have to post cash collateral. Moreover, you might have a risk mitigation strategy that causes you to trade at unfortunate times; this does not affect the stress tests, which are shocks to existing positions, but it does affect the scenario analyses.

Value at risk is estimated every day and tested rigorously against price movements. The existing bank VaR models were not working: they weren't giving the right number of breaks, and the breaks had patterns. This is common, it means you don't understand the centre risk - the risk on most days. If you don't understand the centre risk, you can't be confident you understand the tail risk. You're not running under risk control. So, you try to fix the VaR models in order to learn more about the centre risk. The analysts discovered that the problem was the market prices were strongly affected by the London Whale trading, and by counter-trading fighting his positions. There are two ways to think about this. You could say that it's impossible to estimate VaR because it's a self-referential problem; the VaR depends on our trading. That would normally lead to either trading being shut down, or a separate risk management framework being set up for the strategy that explicitly considered the issues raised by price impact. The other thing you could say, and this is what the risk managers chose, is to say the problem is with the prices we're using to back test the VaR. We need to explicitly adjust for liquidity risk and price impact. The danger here is that you're now testing your risk assumptions against your opinions rather than objective market measurements. It's not crazy, sometimes it's the best thing to do when you have a deep understanding of trading markets, but it's always dangerous. After doing this for a while, the risk managers decided to stop.

Okay, now what should have happened? The scenario tests showed potential mark to market losses large enough that this should have been on the list of things the Chief Risk Officer briefed top management, including the CEO, on. In my opinion, it even merited reporting to the risk committee of the board. The message would have been, "We have this highly successful European credit hedging operation that's generating large profits, and gives us significant protection in a major credit downturn, as we want. But our scenario analyses show that it could have a large mark to market losses we should discuss right now whether we would tolerate $\$ X$ billion losses during quarters without much change in overall credit if we remained confident that the portfolio was doing its job. Moreover, limiting the losses assumes certain trading liquidity that our VaR analyses suggest might not exist even in normal markets, much less during a crisis. In fact, we're not confident about our VaR estimates, so there might be risks we're missing. "The decision would have been made to retain the strategy, but to pull it out of the VaR framework in favour of risk management based on actual positions. Position sizes would have been cut, and the highest leverage parts of the strategy pruned. The result would have been a portfolio less vulnerable to mark to market attack; and if the attack occurred anyway, top management and the board would have been prepared to commit the necessary capital to defence.

Of course, it's also possible that the decision would have been to cancel the strategy; or to leave the strategy under the existing risk managers. But even in the latter case, the CEO would not have been surprised and embarrassed when the losses came to light. Arguably, that did as much damage as the losses themselves. Instead of denying the losses, he would have said they were part of a hedging strategy under risk control, that management and the board had confidence in, and that the mark to market losses was acceptable in light of the long-term program goals. Instead of doing a fire-sale at the worst time, the program could have continued until it returned to profitability, or been closed down deliberately to minimize losses. So how did the risk management message get lost in translation? We think the line-level risk management was unimaginative and timid, but not incompetent. We think the actual trading was aggressive but not unreasonable if the bank had really been 
willing to back it up. We think more information filtered up higher than people later admitted. While top people were not informed as clearly as they should have been, this was more a problem of wilful downplaying of risk than true ignorance about the situation. But we also blame the top risk management because it's part of their job, not only to inform people clearly but to get them to acknowledge being informed. This is the only way to establish clear responsibility for risk. It's not a question of pointing fingers afterward; it's making sure authority and responsibility are in the same place. As it happens, we think authority was pushed down too low, and responsibility pushed up too high, so when losses mounted the people in a position to do something about it didn't feel responsible, and the people responsible didn't have the ability to fix it.

\subsection{Law, Regulation, Comparative Analysis and Significance}

First, there are matters of law and regulation. For example, there are regulations and some laws about accurately describing your business strategy and reporting/calculating risk measures if you are a public company. JPM arguably failed to meet such standards of corporate governance at multiple levels. Among the self-identified failures and weaknesses were misleadingly "favourable" valuations of various positions at different times, failure to execute and monitor a stated strategy, identifying a hedge that had no identifiable hedging characteristics or justification, failure to enforce self-identified risk limits, failure to disclose material information to regulators and investors, and other things. Some argue that this does not prove the need for government involvement, or alternatively that the best and only role for government is to enforce contracts or ensure accurate information so that market discipline will do the rest.

There are economic and ideological components to these arguments, of course. Most developed countries have landed on market-based but not completely laissez-faire approaches to the financial system. We opine that market discipline is generally superior whenever practical but that some market "imperfections" leads to necessary regulation. A complicating factor is that markets are not fixed so it is not clear that what is appropriate and effective in one state of the market is right for others. Many arguments are simply about where and how (and especially who defines and interprets) the lines. One widely recognized trade-off is stability vs. long-term growth, but there are others that are important. Fairness is one that has received increased attention in recent years. Large financial firms (and, the financial system as a whole) may be a source of significant externalities, such as unexpected costs that are paid by those who are not responsible for them, and for local, national, and global economies. It is commonly but not universally believed that the government has the ability and the responsibility to manage this. Key components are regulation and deposit insurance.

The importance of these were demonstrated fairly conclusively during the great depression in the US and the recent financial crisis, as well as a long history of bank failures. But then, some opine that the London Whale never really put JPM at risk of significant failure so no government involvement was merited. But the events occurred in the aftermath of JPM's being the poster-child for strong risk management during the crisis. Approximately the same time there were credible allegations that supposedly "arms-length" measures of bank safety such as LIBOR were being manipulated. The events of the London Whale undercut the sense that good risk management was possible and reinforced the view of many that banking is a special business that cannot regulate itself effectively. But then this can be a nanny-state vs reasonable social trade-offs.JP Morgan Chase's trade abuse and risks involved appear to paint derivatives as evil. However, they are neither evil nor capable of being one. A claim of this nature is logically and functionally the same as claiming that cars are evil because they might cause accidents. Remember people can be unethical, but often this is fueled by plain greed, and those people can find ways to manifest their greed. Look at this logically for a moment and one will see the error in argument. The syllogism (more or less) is: (a) events associated with derivatives cause pain; (b) pain is symptomatic of evil; $(a+b)$ therefore derivatives are evil.

This is obviously incorrect. One can have similarly flawed premises with the "speculation / arbitrage is bad" claim. One can dispense with the arbitrage error up front: In "pure" arbitrage, losses are impossible by definition. Most forms of arbitrage in the real world carry some (usually minor) risks, but the advantage is efficient, consistent and liquid pricing for everyone. It is the abuse of these financial instruments by greed that lead to pain, not derivatives on their own. Some might say this is a pedantic distinction, but much flows from the consequences. Some of the great tragedies in finance are often linked with people who have exhibited untold greed together with harmful eco and unwillingness to admit wrongdoing. Look at the case under review at the moment. The perpetrator, believed to the London Whale, has displayed, amongst others the following these similar basic character and attributes: possibly Mr. Iksil displayed little awareness of the boundaries of his own knowledge; there was a demonstration of pride; either pomposity of coming across as being more knowledgeable across than having greater expertise than he actually did, or with manifesting knowledge having disdain for those people who might have questioned his expertise, and a deep fear of failure together with an incapacity to admit his part in the whole calamity. In "cash" products, these character qualities end up having fairly benign effects. For the most part, the losses are limited to the amount of the initial investment.

Credit default swaps get a bad name because they permit leverage, an attribute that encourages the rub (Fletcher, 2019). In nearly every massive scale loss driven by derivatives, the trader could actually be structuring the gamble such that he is taking a small, but highly certain amount of money up front with a simultaneously small risk of complete calamity in the future. This is a decision that is often made based on the fact that the trader has never moved a large amount of the securities, and hence the risk in the past might have been small. In most cases, a trade can go on for months or even for a year making the gambles and returns come out to be successful, and this might create a good and small feedback loop to encourage his behaviour. Nevertheless, rare events, by definition, means that people outside actually knew little about them, the way that the can be predicted and how the trader can model their impacts. In research, the events (the rare ones) occur far more often that any statistical measurement would dare to admit (Augustin et al., 2016; Duffie, 2018). This means that the inevitable will happen. 
The rare events often come along and then wipes out the gambles. If it was just some pure equity investment type, then the losses would have been controlled; however, for derivatives, because of their nature can only speed up the losses.

However, the banks failed to put in mind the need of hiring experienced leaders who could oversee and avoid the likelihood of the trading malpractices thus leading to declined profits as a result of the lobbed regulators and lawmakers weakening the provisions of the rule. Additionally, the chief investment office (CIO) failed to mitigate the risks to the London bank, thus leading to large credit positions which caused the unusual market adjustments encouraging the hedge funds (Giancarlo, 2018). Collectively, some of the malpractices were fully linked to trader Iksil, and it is believed that the trader was involved in the market manipulations thus inconveniencing the banks to obtain profit margins which in turn were to benefit other London investors. In other words, if the payoff is linear and people can be comfortable taking risks they know they cannot fully understand, or the risks belong to a domain that is 'capable' of being modelled statistically, then go ahead, which the benign risk is taking. Therefore, the evil which people ascribe to derivatives is, in fact, the latter type of risk taking; arrogant, over-confident, and non-linear, leveraged bets. The mechanical features of derivatives namely their leverage and second-andhigher order derivatives (specifically, gamma) exacerbate this overconfidence and cause the disastrous effects.

\subsection{Evidence of Survivorship Bias}

Another mistake people make is to select the "outliers" of derivative use. These are extreme examples being used to make a general case. This is simply not right. Derivatives do much good. To revisit the computer analogy, they are capable of many positive things and - millions of times daily, and are used without a hitch; both for hedging and speculation. People do not just care about whether, on balance, their individual use is "good" or "bad". People care about the scope and amount of their end results. Nevertheless, even on that measure, the dollar to social value of all types of derivative use is greater than the bad (outcomes that were primarily, specifically and significantly related to the use of derivatives). Thus, it is important to the magnification of the point from the case study. From a technical angle related to two (and a half) points: gamma, the marking of OTC derivatives positions and collateral haircuts. It is the accelerative property of derivatives (their gamma) that provide the real explosive force (in both directions). Essentially, gamma means that it is increasingly difficult to hedge and mitigate losses once they begin occurring on a "short gamma" position. In other words, losses beget losses at an increasing rate and have no theoretical limit.

Correspondingly, the vast amount of derivatives is non-exchange traded. That is, they are struck between two entities, which is usually a trader and a broker. Every day, positions are marked to market - that is, normally, some amount of the profit and loss on that particular trade flows from one to the other every day. Brokers set these margin requirements on their view of the client. Part of their view is credit risk; if the broker's counterparty is a large fund, it might be a very small margin. They charged eight times. Otherwise it can simply be how they view their customers. In other words, two traders can hold the exact same position with a counterparty, but are paying different amounts to keep the trade alive every day. Usually, banks have the ability to nearly arbitrarily change these margins whenever they like, which means so much so that they can force traders out of their positions if the bank doesn't like the overall risk on their book.

To keep these trades alive, the JP Morgan Chase has to send funds or have sufficient overall margin in its facility with broker. Most of the time, cash is required. If it has a good client, the broker can post other forms of collateral. However, in taking this risk, banks will deduct a percentage off the value of that collateral to allow for its rapid conversion into cash. This is called a haircut. Thus, in a crisis situation, you get vicious feedback loops which are not well understood by academics or the general public, after all, they are a practical, real world element of finance rather than the theoretical stuff taught in schools. The short gamma position gets pushed hard, causing losses. The broker does not like the position, so they increase the daily margin. As a result, you are getting strapped for cash trying to fund the position. One begins posting other securities as collateral on the margin facility. The broker takes this as a bad sign. His risk department then forces him to aggressively haircut the position to reflect their dim view of your trading ability. The position worsens. The cycle repeats until they tap you out and you are out of the game. Variations of this vicious loop is what happened in nearly all of the financial disasters.

\section{The Ethics Connection and Violation}

Scientific and technological advancement coupled with economic realities and pluralistic worldview requires that professionals in general and finance professionals in particular, like to make ethical consideration in their work (Hoekstra, \& Kaptein, 2020). Ethical directives are a source of major debate as this debate brings forth varied opinion and feelings. This is so, because, some people refer to ethics as merely personal opinions. This kind of thinking seems unfounded as basing ethics on personal opinions, intuition or unexamined beliefs of individual people can only work theoretically but difficult to implement in reality (Hoekstra \& Kaptein, 2020). It is therefore important that all professionals have a general understanding of the concepts, principles, and theories relating to ethics. This is framed well by Hawkes (2019) who mentions that there is a need to develop hearts as well as the minds.

As a discipline ethics is regarded as a critical way to understanding, analysing and distinguishing right from wrong, good from bad since it relates to the connections of sentiments of well-being. The determinants of ethics are assessed using approaches of formal theories and code of conduct. These codes of conduct include codes that are designed for different professions and world religions. Ethics is not a static position but rather an active process (Hoekstra, \& Kaptein, 2020: Dziubaniuk \& Nyholm, 2020). Thus, it is common for theorists and philosophers to use the expression of doing ethics to refer to ethical consideration when performing an action or exhibiting behaviour that is in line with ethics. Another assertion on the debate for ethics is that in as much as people believe and hold different view of ethics one must be in a position to justify their 
ethical standpoint, support their beliefs and assertions through sound and logical arguments (Grant, 2018). Evaluations arrived at from practice of ethics demand a proper balance of emotion and reason (Grant, 2018). This is because basing emotions on ethical related discussion and argument as well as making decisions does not provide a good foundation.

The difference between ethics and morals pertains the belief system, behavioural conduct (Hoekstra, \& Kaptein, 2020). If a person behaves, or rather exhibits unamiable traits or exudes a character that deifies a code of conduct held by that person's society, community or profession he is referred to being unethical (Grant et. al., 2018).

Banks are in the position to secure the consequences of the credit quality by avoiding moral hazards. The use of good and proper social norms of an institution helps the leaders to explore the roles for codes of ethics in improving ethical norms applicable to the accountability mechanisms required in the financial institutions. Collectively, another study provides that hiring of ethical officers, for instance, the $\mathrm{CIO}$ and the $\mathrm{CFO}$ in an organization reduces the corruption and moral hazards scandals (Jones et al., 2020). It is good for the organizations to offer ethical education to newly hired employees that seem to be less ethical to avoid future misconduct in the financial sectors and offices, which in turn minimizes the corporate accounting scandals (Mutnuru, 2016).

\subsection{Virtue Ethics Theory}

Unlike the other approaches which focus on action as the object of moral evaluation this approach focuses on the person performing the action (Krambia-Kapardis, 2016). Rather than taking account of what people do and the repercussions, it looks at who these people are by analysing their personal qualities. However, it does not take consideration of the physical qualities like height, age and size but on the intangible qualities such as abilities, intentions and motives (Krambia-Kapardis, 2016). By evaluating this intangible quality, it is easier to determine how an individual will behave in a morally problematic scenario and thus evaluation in moral terms is easier. Therefore, through how people act they can be categorized as honest, just or reliable.

In analysing the London whale case study through the virtue ethics framework JPM exhibited unethical behaviour by violating virtues like honesty, prudence and humility (Krambia-Kapardis, 2016). On the honesty virtue JPM violated the virtue ethics as it did not immediately reveal its losses. Iksil the senior trader and Ina Drew head of CIO never revealed the losses it was making until the media discovered and made the news public. The information was revealed to Bloomberg media by counterparties from hedge banks and rival banks who coined the term London whale signifying Iksil's big risks behaviour in the credit derivatives market. It wasn't until the journalists called to confirm the allegations that JPM considered going public (Pilkington, 2016). Even when the news blew up JP Morgan remained non-transparent and announced the bank had only lost 2 billion. On matter of prudence JPM as an individual entity is guilty and thus unethical of not having performed its institutional role of safeguarding enormous and risky trades (Krambia-Kapardis, 2016). Iksil as an individual himself demonstrates unethical behaviour and lack of prudence by engaging in large trade on the credit derivatives. The culture at JPM left much to desire with questions whether it naturally nurtured intemperateness. JPM portrayed a lack of risk management which all participants in the financial market should exhibit as it's among the code of ethics within the financial industry. This also revealed a lack of government oversight on the financial industry.

Prudence can be inculcated by encouraging transparency which in turn discourages intemperateness. When senior management are strict and demand that all employees uphold transparency in their undertakings, the financial professional may be prudent and thus protect the bank's credibility. Lack of such ethics and demands pushed Iksil and his colleagues to act immoderately, possibly because they were used to lack of regulation by the JPM management. JPM inadequacy is evident as it was unaware on the risk and size of trades. The CEO Jamie Dimon showed a lack of humility throughout the fiasco. When questioned, Dimon appeared to show that he was aware of the transactional costs at the bank which wasn't the case. He dismissed the media reports about the SCP terming them as "a complete tempest in a teapot" (Krambia-Kapardis, 2016). Dimon and his bankers exhibited an overly confident attitude over JPM structures to detect and handle risks. He demonstrated unethical behaviour by continually defending against government regulation and also verbally criticizing Dodd-Frank legislation and the Volcker Rule.

In view of the London Whale, it is clear that JPM had a rough time in the actualizing of the shortcomings in the virtue ethics, thus inconveniencing the functions of market controllers in the corporate stock. These problems expose the shareholders to financial penalties for misconduct caused by the respective leaders, especially those working under the fiduciary duty. For example, London Whale and JP Morgan was put on liability for mismanagement of the trader's money by the USA and UK regulatory body and requested to pay the fines. However, despite the severe fines imposed to the banks, it is evident that the penalties the JP Morgan was to pay the investors as requested by the USA and UK officials indicate the perils in adopting of the moral approaches regarding financial issues mainly to maximize on the profits.

\subsection{Consequentialist Ethics Theory}

The consequentialist ethics hold that the moral acts can be determined by looking at the consequences that result from performing a certain action (Hoekstra \& Kaptein, 2020). This involves both the real and expected consequences of an action. Ideal behaviour is considered as that which the consequences are desirable and unethical when the consequences are undesirable (Hoekstra \& Kaptein, 2020). The purpose or end of a certain action then determines the measure against which actions are weighed. The consequentialist ethics are also referred as teleological ethics which is derived from Greek word, telos that mean 'end'. When the ends are satisfying their own gain, they are considered as intrinsic while termed instrumental if they are used to attain another goal. Consequentialist theory can be classified as monistic or pluralistic depending on the 
quantity of intrinsic ends that it uses. Monistic theories imply that there is only one intrinsic end which all other ends are set to achieve and the measure through which all actions can be morally evaluated (Dziubaniuk \& Nyholm, 2020). Whereas pluralistic teleological theories posit two or more intrinsic ends.

In the case study of JP Morgan, the senior trader was given conflicting directives by the management which the taskforce attributed as the major reason for the huge losses. Iksil was asked to replicate the profit gains of 2012 while also being directed by Dean the head of CIO to hedge risks signifying the pluralistic nature of teleological theory of ethics. A conflicted Iksil devised a strategy to use credit derivatives in attempt to simultaneously achieve this end goals which ultimately resulted to huge losses. The teleological theories can also be categorized with respect to the nature of end they have been used for. Hedonism refers to teleological theory used as a means to achieve pleasure or delight (De Graaf, 2019; Caulfield, et al., 2020). This measurement standard of action stretches to the initial stages of classical antiquity.

\subsection{Utilitarianism Theory}

Utilitarianism implies that actions are evaluated by the usefulness or utility of their consequences. It is meant to promote the greatest good/pleasure/happiness and result to the least amount of pain or suffering. The phrase "providing the greatest good for the greatest number" of people that an action results to is commonly inferred to by utilitarian to determine that which is good and ethical for the society (Mudrack\& Mason, 2019). It is estimated that at one time JPM lost close to 2 billion on a single day. The huge losses made by the company were felt far and beyond the company's walls. When risks are made by individual entities, it could result to huge gains yet the same could happen with losses. The downside is that individual risk is transferred and reallocated into the system which affects the whole economy. Impact of the JPM losses culminated to the loss of employment of not only the traders involved but 19,000 JPM employees also got their job contracts terminated (Hoekstra, \& Kaptein, 2020). Therefore, by analysing the JP Morgan's London whale case study through the utilitarian approach it is sufficient to conclude that the company was unethical in pursuing its business strategies. The greatest good of the society was not achieved rather pain and suffering through decreased investments, loss of jobs and loss of welfare was the result.

\subsection{Deontology Ethics Theory}

This approach in ethics is focused on duties and rules. Immanuel Kant, a British Philosopher is most credited with this deontological way of thinking. Kant was of the idea that individuals have the intuition to automatically act rationally and morally. (Xu et al., 2016). According to Kant, as cited in XU et al. (2016), actions can be described as moral only when they are dutiful. Kant revealed that acting from rationality is more appropriate when compared to emotions which are hard to exercise a control over. Deontological is coined from a Greek word Deon that means "one must." The proponent of this theory stipulates that ethical behaviour is achieved thorough strict adherence to a set of rules or obligations which cannot be compromised on. Deontologists refer to these obligations as duties. The deontological and teleological theories differ on the consequences that an action under consideration is given. Deontologists believe that the results of an action are not an efficient method to determine a moral character when compared to rules. They posited that keeping a promise is does not entirely mean that there is a reward to be gained rather a moral duty to be cultivated for those who consider themselves as ethical (XU et al., 2016).

Analysing the JPM case study through the deontological approach reveal serious violation of ethics. JPM defied the Volcker rules which are meant to have a regulatory effect on risk management of financial institution like banks, hedge funds and so on. Deontological ethics pertain dutifulness in following the rules which the JPM violated as it did not follow this rule (Osterberg, 2019). When Braunstein, a JPM official appeared before the subcommittee he asserted that April 13 earnings were consistent with ultimate outcome related to Volcker rule. Also, when JPM had held a press, it implied that it had used the SCP to hedge risk but when it was mandated to show how and analysis were made into the matter this was not the case. It was found that the SCP was not compliant with the Volcker rule. Evidences were also produced containing proof that JPM had written a letter to the regulatory committee to express that it was concerned the SCP would likely violate the Volcker rule (Bao et al., 2018). Additionally, when presenting an analysis of the CIO to investors so that it could get the green light to continue with it never mentioned the legal analysis that had been done by the regulatory committee.

\subsection{The Social Contract Theory}

Thomas Hobbes believed that in a state of nature people would rationally choose to have some form of government he termed this as the social contract (Mudtrack et al., 2019). He postulated that this social contract is entered as people are willing to free up certain right to a governing authority in exchange of security and common benefits. This is a dilemma that existed since ancient times and until now where there is a need to balance between human desire for freedom and human desires for order (Jahn \& Bruhl, 2018). This kind of contract naturally exists between organizations and the society. The corporation trades perpetual life and limited liability for corresponding duties towards the society (Jahn \& Bruhl, 2018). Theorists that advocate for social contract explain that in all communities just like countries enact rules for the good of all its members. All institutions and organizations have a rule book that each and every one is expected to follow to be allowed as a member of that group. When these rules are broken the members face elimination from the group. (Vogelgesang, et. al., 2020).

The effects of unscrupulous business strategies by JPM resulted to huge losses which were translated to the economy and ended up affecting the general public. The loss of welfare and negative effects to the society represent a direct violation of the social contract JPM automatically has with the investors and the society as a whole. The contract is that a business stays operational as it requires the people and if it acts in a manner that does not benefit the society then it is unethical for it to 
continue operating as it endangers them. JPM conduct is unethical as per this theory as it increased risk before informing those mandated to regulate against extreme risk dispersion strategies. The JP Morgan failed to take the most appropriate business measures because of the lack of ethical aspects among the traders, which made the corporate have a difficult time handling its business derivatives. Additionally, the corporate also failed to exercise its mandated duties of risks management when dealing with credit derivatives due to lack of a clear code of ethics within JPM leading to huge losses of money. Moreover, the bank was subjected to the risks because of the unrealized ethical tensions among the executives, which made it hard to figure out the legitimate business conduct and appropriate transgressions for the trader's sake.

A banks' management should not only focus on their financial performance, instead they should also pay attention to how prosperous and secure is the inner growth of their financial sector. Such considerations help it to avoid further fines due to emergence of the mismanagement of the investors' funds and other trading factors to buy securities and bonds (Bao et al., 2018). Business ethics should be the core factor in achieving the prior mentioned factors because it allows the management to involve the outsiders such as the government, and corporations in the decision -making process to diffuse the variety of wisdom regarding financial matters. The involvement helps the concerned and consolidated individuals portray their ethics in discussing the ways of improving the profitability index of the given financial institution. In this regard, the JPMorgan and London Whale ignored the suggestions made by traders regarding the signs of the deficits, thus leading to uncontrolled losses for a couple of years. Therefore, the need of ethical theories should be considered since it helps the corporate to distinguish between what is good and bad concerning the betterment of financial sectors which in turn attracts more investors leading to achievements of high-profit margins.

\section{Conclusion}

First, there are matters of law and regulation. For example, there are regulations and some laws about accurately describing your business strategy and reporting/calculating risk measures if you are a public company. JPM arguably failed to meet such standards of corporate governance at multiple levels. Among the self-identified failures and weaknesses were misleadingly "favourable" valuations of various positions at different times, failure to execute and monitor a stated strategy, identifying a hedge that had no identifiable hedging characteristics or justification, failure to enforce self-identified risk limits, failure to disclose material information to regulators and investors, and other things. Some argue that this does not prove the need for government involvement, or alternatively that the best and only role for government is to enforce contracts or ensure accurate information so that market discipline will do the rest (Duffie, 2019). There are economic and ideological components to these arguments, of course. Most developed countries have landed on market-based but not completely laissez-faire approaches to the financial system.

Market discipline is generally superior whenever practical but that some market "imperfections" lead to necessary regulation. A complicating factor is that markets are not fixed so it is not clear that what is appropriate and effective in one state of the market is right for others. Many arguments are simply about where and how (and especially who defines and interprets) the lines. One widely recognized trade-off is stability vs. long-term growth; but there are others that are important. Fairness is one that has received increased attention in recent years. A large financial firm (and the financial system as a whole) may be a source of significant externalities, such as unexpected costs that are paid by those who are not responsible for them, and for local, national and global economies (Valine, 2018). It is commonly but not universally believed that government has the ability and the responsibility to manage this. Key components are regulation and deposit insurance.

Furthermore, another study considers ethical behaviour as being comprehensive, and if put into considerations while running the companies' activities, it boosts the stability of profits yield. The virtue is essential during the preparation of financial statements for accountability purposes and the utilitarian goal for generating of the overall benefits, for instance, the London Whale failed to apply this theory thus subjecting the bank to subsequent heavy losses. In the context of internal and external controls, the use of instrumental and virtue ethics is important because it helps the banks to remain vigilant and proactive about the financial matters by being accurate in performance of principles of accounting. For the case of JP Morgan, statements from the internal and external structures varied, leading to instances of misconduct due to the lack of ethical considerations by the CIO and CFO, whose actions or inactions directly led to the bank making significant losses. Therefore, use of the virtue ethics and instrumental ethics in any financial setting tries to settle the likelihood of future and current financial discrepancies due to poor controls among the senior and subordinate management (Schafer, 2019). On the other hand, ethics might be accompanied by human imperfections since some individuals are hard to implement virtue ethics and put in practice. This affects the wellbeing of individuals and on how they handle issues at the corporate level. The importance of these were demonstrated fairly conclusively during the great depression in the US and the recent financial crisis, as well as a long history of bank failures.

Some say the London Whale never really put JPM at risk of significant failure so no government involvement was merited. But the events occurred in the aftermath of JPM's being the poster-child for strong risk management during the crisis. Approximately the same time there were credible allegations that supposedly "arms-length" measures of bank safety such as LIBOR were being manipulated. The events of the London Whale undercut the sense that good risk management was possible and reinforced the view of many that banking is a special business that cannot regulate itself effectively (KrambiaKapardis, 2016). The Volcker rule is meant to discourage banks from engaging in high-risk speculation creating an unacceptable level of systemic risk. To increase regulation and reduce moral hazard pervasive among banks. A lot can be gathered from the London Whale study and certain research possibilities may be created from it. However, the one involving 
the case as it relates to the Volcker rule is simply too appealing. One aspect of the Volcker rule is to remove proprietary trading from banks (Avci et al., 2018). Proprietary trading is considered a moral hazard for systemically important banks. Banks may have the tendency to take excessive risk as the cost is incurred by the government / tax payers as witnessed in the last financial crisis and the decision of the government to step and rescue the big bank.

In-depth, future research possibilities have to consider the provision of advanced regulations to guard the financial systems and traders. For instance, there should be good risk management plans that do not ignore other metrics as experienced before. The higher management will have to foresee how the limitations are imposed on the market values of the SCP to avoid further breaches to be caused in other bank metrics. The accounting sectors apart from the use of GAAP they will also have to consider other sub-methods for handling the financial matters (Krambia-Kapardis, 2016). For instance, the use of the integrated financial information systems for purposes of accuracy to prevent the London whale from economic depressions (Bondoc \&Taicu, 2019).

The other thing is that what constitutes FDIC-funds and what does not is something that ethicists will argue about, and a lot of the regulator effort involves defining those terms. They will have attorney arguing the meaning of every single word in the legislation. Also, banks cannot "hide" anything. What they can do is to hire lots of lawyers and lobbyists and get rulings from the regulators that certain things or are not covered. Part of the chess game involves figuring out which regulator issues which ruling. Once the regulator issues a ruling, then the lawyers in a bank will issue a policy statement, and which point the people in the bank will argue over the meaning of every single word in that policy statement. The Volcker Rule therefore fails in its intention. To try to determine regulation based off of the intention of why someone holds something is too hard and wasteful. It is very difficult to segregate the types of transactions which are helping customers and those which are strictly proprietary.

What Dodd-Frank is, is instructing through the law what certain agencies ought to try to do. Banks cannot do things that way because then the regulatory agencies proceed to fuss around to figure out how to do what the law says. For example, Dodd-Frank had a provision that banks must give qualified mortgages, and if they do not give them then there are stiff penalties. The act never went on to define what a qualified mortgage is. Hence, banks are reluctant to make loans. For the Volcker Rule, it's the same case. There is no hardwiring in the law for how to prevent banks from speculating with their own money. The law just says banks must not do proprietary trading.

Comparatively, reflecting on the prior mentioned features about the ethics and regulations it is of great significance for an individual to know that the two can be implemented. Reasonably, ethics and regulations work alongside one another, whereby ethics without regulation, there will be the likelihood of little value in the two aspects. Notably, ethics is the main determinant since, in any given organization, most of the regulators consider the image of regulations which depends on the ethical considerations. This simply implies that the use of rules and regulations that are strict enough helps in getting rid of the ambiguous distinctions in any given organization. However, the London Whale failed to implement such regulations making the traders get submerged to unethical issues which in turn exposed the JP Morgan banking system to more risks of moral hazards (Romious et al., 2016).

The moral hazards are believed to arise as a result of lack of ethics among the senior management and in the long run caused the financial crisis in banking institutions which in turn affected the wellbeing of the traders. Alternatively, the case of the London Whale calls for a need to apply ethics, for example, in the use of the use credit default swaps (CDS) in hedging against risks and acts as insurance for regulation purposes (Brinded, 2017).

With the resultant disaster which nearly led to the collapse of the whole market, the government initiated the rules pointing out that in case of the violations, heavy fines were to be imposed, as a deterrence measure. In contrast, it is beyond doubtful reasoning that ethics can be implemented with regulations since during the law creation and interpretation ethics is used to make the formulations. Finally, any firm should be fair and consider the need for subjective values while making the laws to achieve the proper functioning of ethics in the handling of administrative duties.

\section{References}

1. Abdelaziz, F. B., Abed, M., (2018), 'Ethics in Investment and Portfolio Selection: A Review', In Financial Decision Aid Using Multiple Criteria, 197-217, Springer, Cham

2. Augustin, P., Subrahmanyam, M. G., Tang, D. Y., Wang, S. Q., (2016), 'Credit default swaps: Past, present, and future', Annual Review of Financial Economics, Vol. 8, 175-196.

3. Afsar, B., Shahjehan, A., (2018), 'Linking ethical leadership and moral voice: The effects of moral efficacy, trust in leader, and leader-follower value congruence', Leadership \& Organization Development Journal, Vol. 39 (6), $775-793$.

4. Bao, J., O'Hara, M., Zhou, X. A., (2018), 'The Volcker Rule and corporate bond market making in times of stress', Journal of Financial Economics, Vol. 130 (1), 95-113.

5. Bondoc, M. D., Taicu, M., (2019), 'Ethics in financial reporting and organizational communication', Scientific BulletinEconomic Sciences, Vol. 18 (3), 168-174.

6. Bonin, P., Gelin, M., Laroche, B., Méot, A., (2020), 'Survival Processing of the Selfish Gene?', Adaptive Memory and Inclusive Fitness, Evolutionary Psychological Science, Vol. 6 (2), 155-165.

7. Brinded, L., (2017), 'The 'London Whale' trader who made a $\$ 6.2$ billion trading loss says he'd welcome a lawsuit to 'retrieve' his 'stolen' life', Retrieved from https://www.businessinsider.com/london-whale-trader-bruno-iksil-jpmorganlawsuit-job-book-2017-3?IR=T

8. Cavusgil, S. T., Deligonul, S., Ghauri, P. N., Bamiatzi, V., Park, B. I., Mellahi, K., (2020), 'Risk in international business and its mitigation', Journal of World Business, Vol. 55 (2), 101-178. 
9. Caulfield, J. L., Baird, C. A., Lee, F. K., (2020), 'The Ethicality of Point-of-Sale Marketing Campaigns: Normative Ethics Applied to Cause-Related Checkout Charities', Journal of Business Ethics, 1-16.

10. Conrad C.A., (2018), 'Tools of Ethics for Management', In: Business Ethics - A Philosophical and Behavioral Approach, Springer, Cham.

11. Chuang, P. J., Chiu, S. F., (2018), 'When moral personality and moral ideology meet ethical leadership: A three-way interaction model' Ethics \& Behavior, Vol. 28 (1), 45-69.

12. De Graaf, F. J., (2019), 'Ethics and behavioural theory: How do professionals assess their mental models?', Journal of Business Ethics, Vol. 157 (4), 933-947.

13. Dziubaniuk, O., Nyholm, M., (2020), 'Constructivist approach in teaching sustainability and business ethics: a case study', International Journal of Sustainability in Higher Education.

14. Duffie, D., (2019), 'Prone to fail: The pre-crisis financial system', Journal of Economic Perspectives, Vol. 33 (1), 81 106.

15. Duffie, D., (2018), 'Financial regulatory reform after the crisis: An assessment', Management Science, Vol. 64 (10), 4835-4857.

16. Fletcher, G. G. S., (2019), 'Engineered Credit Default Swaps: Innovative Or Manipulative', NYUL Rev., Vol. $94,1073$.

17. Garicano, L., Rayo, L., (2016), 'Why organizations fail: Models and cases', Journal of Economic Literature, Vol. 54, No. 1, 137-192.

18. Giancarlo, C., (2018), 'Cross-border swaps regulation version 2.0. A Risk-Based Approach with Deference to Comparable Non-U.S. Regulation', white Paper Release Number 7817-18

19. Grant, P., Arjoon, S., McGhee, P., (2018), 'In pursuit of eudaimonia: How virtue ethics captures the self-understandings and roles of corporate directors', Journal of Business Ethics, Vol. 153 (2), 389-406.

20. Grima, S., Thalassinos, E. I., (2020), 'The Perception on Financial Derivatives: The Underlying Problems and Doubts', In: Financial Derivatives: A Blessing or a Curse?, Emerald Publishing Limited.

21. Greenwood, M., Freeman, R. E., (2018), 'Deepening ethical analysis in business ethics', Journal of Business Ethics, Vol. 147 (1), 1-4.

22. Hassan, N. D., Azhar, N. A., Daud, M. M., Ruslan, M. F., (2017), 'The Study of Ethical Work Behaviour and Job Performance', ICOPS2017 e-Proceedings, 866.

23. Hawkes, D., (2019), 'Against Financial Derivatives: Towards an Ethics of Representation', Journal of Interdisciplinary Economics, Vol. 31 (2), 165-182.

24. Hoekstra, A., Kaptein, M., (2020), 'The Integrity of Integrity Programs: Toward a Normative Framework', Public Integrity, 1-13.

25. Huan, X., Parbonetti, A., (2019), 'Financial derivatives and bank risk: evidence from eighteen developed markets' Accounting and Business Research, Vol. 49 (7), 847-874.

26. Iqbal, Z., Mirakhor, A., (2017), 'Moral Sense and Ethics in Economics and Finance', In: Ethical Dimensions of Islamic Finance, 25-59, Palgrave Macmillan, Cham.

27. Jago, A. S., Pfeffer, J., (2019), 'Organizations appear more unethical than individuals', Journal of Business Ethics, Vol. 160 (1), 71-87.

28. Jahn, J., Bruhl, R., (2018), 'How Friedman's view on individual freedom relates to stakeholder theory and social contract theory', Journal of Business Ethics, Vol. 153 (1), 41-52

29. Jones, M. C., Kappelman, L., Pavur, R., Nguyen, Q. N., Johnson, V. L., (2020), 'Pathways to being CIO: The role of background revisited', Information \& Management, Vol. 57 (5), 103-234.

30. Krambia-Kapardis, M., (2016), 'Contributing to Financial Crisis Prevention through Banking and Financial Services Regulation', Banking and Financial Services Policy Report.

31. Lartey, F. M., (2020), 'Ethical Challenges of Complex Products: Case of Goldman Sachs and the Synthetic Collateralized Debt Obligations', International Business Research, Vol. 13 (6), 115-115.

32. Leins, S., (2018), 'Stories of capitalism: inside the role of financial analysts', University of Chicago Press.

33. Lewitinn, L., (2016) , April 27, 'How Buffett used 'financial weapons of mass destruction' to make billions of dollars', Retrieved September 29, 2020, from https://finance.yahoo.com/news/how-buffett-used--financial-weapons-of-massdestruction--to-make-billions-of-dollars-175922498.html

34. MacIntyre, A., (2016), 'The irrelevance of ethics', In: Bielskis, A., Knight, K., (Eds.), Virtue and Economy: Essays on Morality and Markets, Routledge, 19-34.

35. Mudrack, P. E., Mason, E. S., (2019), 'Utilitarian traits and the Janus-Headed model: Origins, meaning, and interpretation', Journal of Business Ethics, Vol. 156 (1), 227-240

36. Mutnuru, S., (2016), 'The role of internal controls on employees' engagement in small organizations', Journal of Business Studies Quarterly, Vol. 7 (4), 102-114.

37. Natarajan, S., (2018), May 17, 'Pope Calls Derivatives Market a 'Ticking Time Bomb', Retrieved September 29, 2020, from https://www.bloomberg.com/news/articles/2018-05-17/pope-goes-off-on-cds-market-calls-derivatives-ticking-timebomb.

38. Neuhann, D., Sockin, M., (2020), 'Risk-sharing, investment, and asset prices according to Cournot and Arrow-Debreu', Working Paper, University of Texas at Austin.

39. Osterberg, J., (2019), 'Deontological Ethics: Assessment. In Towards Reunion in Ethics', 61-92, Springer, Cham. 
40. Romious, T. S., Thompson, R., Thompson, E., (2016), 'Ethics training and workplace ethical decisions of MBA professionals', Journal of Education and Learning, Vol. 5 (1), 190-198.

41. Rocchi, M. Thunder, D., (2019), 'Can a good person be a good trader? An ethical defense of financial trading', Journal of Business Ethics, Vol. 159 (1), 89-103.

42. Sale, H. A., (2013), 'JP Morgan: An Anatomy of Corporate Publicness', Brook. L. Rev, Vol. 79, 16-29.

43. Schafer, H., (2019), 'On Values in Finance and Ethics: Forgotten Trails and Promising Pathways', Springer.

44. Schoen, E. J., (2017), 'The 2007-2009 financial crisis: An erosion of ethics: A case study' Journal of Business Ethics, Vol. 146 (4), 805-830.

45. Smimou, K., (2020), 'Corporate culture, ethical stimulus, and managerial momentum: Theory and evidence', Business Ethics: A European Review, Vol. 29 (2), 360-387.

46. Toms, S., (2019), 'Financial scandals: a historical overview', Accounting and Business Research, Vol.49 (5), $477-499$.

47. Trang, P. T. M., Tho, N. H., (2017), 'Perceived risk, investment performance and intentions in emerging stock markets', International Journal of Economics and Financial Issues, Vol. 7 (1).

48. Valine, Y. A., (2018), 'Why cultures fail: The power and risk of Groupthink. Journal of Risk Management in Financial Institutions, Vol. 11 (4), 301-307.

49. Vogelgesang, G. R., Crossley, C., Simons, T., Avolio, B. J., (2020), 'Behavioral Integrity: Examining the Effects of Trust Velocity and Psychological Contract Breach', Journal of Business Ethics, 1-16.

50. Vujnovic-Gligoric, B., Jakupovic, S., Šupukovic, V., (2018), 'Ethics in Finance in Emerging Markets', In; Regulations and Applications of Ethics in Business Practice, 165-205, Springer, Singapore.

51. Xu, Z. X., Ma, H. K., (2016), 'How can a deontological decision lead to moral behavior? The moderating role of moral identity’, Journal of Business Ethics, Vol. 137 (3), 537-549. 